\title{
Characterization of the Woody Vegetation of Savannah Ecosystems of Mayo-Danay Division in the Sudano-Sahelian Zone of Cameroon
}

\author{
Bakoulou Ngamo Africa ${ }^{1, ~ *, ~ S o u a r e ~ K o n s a l a ~}{ }^{1}$, Ibrahima Adamou ${ }^{2}$ \\ ${ }^{1}$ Department of Biological Sciences, Faculty of Science, University of Maroua, Maroua, Cameroon \\ ${ }^{2}$ Department of Biological Sciences, Faculty of Science, University of Ngaoundere, Ngaoundere, Cameroon
}

Email address:

afbakoulou@gmail.com (B. N. Africa)

${ }^{*}$ Corresponding author

\section{To cite this article:}

Bakoulou Ngamo Africa, Souare Konsala, Ibrahima Adamou. Characterization of the Woody Vegetation of Savannah Ecosystems of MayoDanay Division in the Sudano-Sahelian Zone of Cameroon. Journal of Plant Sciences. Vol. 8, No. 3, 2020, pp. 41-56.

doi: $10.11648 /$ j.jps.20200803.11

Received: March 9, 2020; Accepted: March 30, 2020; Published: April 29, 2020

\begin{abstract}
Phytodiversity is a vital and capital element for survival of humanity. This study aims to characterize the floristic diversity and the structure of the woody vegetation of the Mayo-Danay division in the Sudano-Sahelian zone of Cameroon. The transect method was used for the floristic surveys. The experimental design consists of four (04) treatments which are the subdivisions and three (03) repetitions, or three (03) villages, per treatment. In the savannah ecosystem of each village, a transect (500 $\mathrm{m} \times 20 \mathrm{~m}$ ) was installed and along each transect, all woody trees with a dbh $\geq 10 \mathrm{~cm}$ at $1.30 \mathrm{~m}$ are inventoried, the diameter is measured as well as the height. The villages surveyed are as follows: Djelme, Gouma and Nouldaina in Gobo sub-division; Bangana, Kononaye and Tchalawa in Guere sub-division; Madalam, Sadamakou and Vagandja in kaïkaïsubdivision; Kalfoucenter, Bougaye and Ngalaï in Kalfou subdivision.The analysis of variance permitted to realize the comparison between the different sites and the Fisher's LSD test allowed to make the comparison between the averages, and all was performed by Statgraphic +5.0 Software.The total specific richness is 57 species belonging to 43 genera and 26 families out of 36 surveys that were carried out in our study area. The spescific diversity in Mayo-Danay varied according to the sites: the Shannon diversity index varies from 2.93 bits in the Bangana site to 4.82 bits in the center of Kalfou; the Pielou Evenness values varied from 0.45 in the Bangana site to 0.67 in the Kalfou-center site; the density was $14.89 \pm 3.27$ stems/ha in the Bangana site to $55.44 \pm 10.49$ stems/ha in the central Kalfou site. The basal area varied between $23.01 \pm 13.17 \mathrm{~m}^{2} /$ ha in the Kononaye site and $109.64 \pm 22.93$ $\mathrm{m}^{2} / \mathrm{ha}$ in the Vagandja site. The evaluation of the horizontal structure in the shape of an inverted J, and of the vertical in the shape of a bell shows a predominance of young subjects and especially of average individuals. The study made it possible to assess the structural characteristic of the woody settlement of the Mayo-Danay division. It thus reveals a regressive evolution of the woody stand with a very high proportion of species of small circumference and medium height. As part of a sustainable and rational management of natural resources in the Sudano-Sahelian environment, this study provides additional information on the current state of the woody populations of Mayo-Danay division.
\end{abstract}

Keywords: Characterization, Woody Vegetation, Savannah Ecosystems, Mayo-Danay Division, Cameroon

\section{Introduction}

Life on earth began with phytodiversity [1]. Without the phytodiversity of our planet, which includes more than 30,000 plant species, animal life as we know it could never have existed [1]. Adapting continuously to the natural dynamics of their environment, phytodiversity quickly invaded almost all of the land that emerged to form the first forests. Phytodiverity has always been intimately linked to human evolution [2]. Numerous studies have revealed the importance of phytodiversity in human food in Africa [3, 4]. Within the whole phytodiversity consumed, there are woody and herbaceous plants [5]. These phytodiversity resources which produce fruits, seeds, tubers, flowers, sap 
and other edible products are as much used for human food as for livestock, in traditional medicine, in agroforestry as fuelwood as lumber and services. They contribute directly to food and play a vital role in the economy of rural populations [6]. In Burkina-Faso, authors noted that natural phytodiversity is for humanity a vital element and a capital which supports multiple needs of a population with a high growth rate [7]. In Cameroon, the average annual growth rate is estimated at $2.7 \%$ / year. In the Far North region this annual population growth rate is around 3\% [8]. This demographic explosion is causing ever-increasing pressure on the phytodiversity of natural ecosystems $[9,10]$.

However, many woody species are today threatened with extinction [11-13] due to over-exploitation of plant species, poor harvesting practices and their poor regeneration [12-14]. The effects of the degradation of phytodiversity include notably the progressive disappearance of a good part of plant and animal species, no longer making it possible to meet the needs of the population [15]. The immediate consequences are the scarcity of certain natural resources and plant species [16-18]. This rate of loss of phytodiversity and the threats of ecological extinction of the resources it abounds are at the heart of international concerns in terms of sustainable management [19]. The need to conserve and protect managing biodiversity on a planetary scale was established within the framework of the Rio Convention, adopted in 1992. Since then, the principle of maintaining phytodiversity has occupied a central place in the various conventions and the various principles of sustainable development.

In Cameroon and more particularly in the Mayo-Dany division, Far Northregion of Cameroon, despite the intervention of the State and Non-Governmental Organizations in the conservation of biodiversity, this pressure on phytodiversity is accentuating as urban centers grow and needs become more pressing. This problem becomes more urgent in the Sudano-Sahelian zone where species are becoming scarce and the pressure on phytodiversity resources is very strong [20]. The Mayo-Dany division which is recognized for its rich potential in phytodiversity [21, 22] in recent years has become the site for the supply of wood energy in the Far North region [23] ; which creates a strong pressure on plant diversity, accentuated by the increase of demography in this division. In fact, in the Mayo-Danay division, important work related to the study of the dynamics and structure of phytodiversity on the influence of various factors has been carried out in protected areas and in savannah ecosystems, notably those [24-28]. Faced with this growing demography, it is important to know the current state of woody stands in Mayo-Danay divisionfor sustainable management, hence the main objective is to contribute to the knowledge of the floristic diversity of the Mayo-Danay division. It is more specifically a question of assessing the current state of the woody floristic composition and of analyzing the structural variability of the woody stand of twelve villages in four subdivisions of the Mayo-Danay division.

\section{Materials and Methods}

\subsection{Study Area}

Our study took place in the Mayo-Danay division situated between the $10^{\text {th }}$ and $11^{\text {th }}$ degrees of latitude North and the $14^{\text {th }}$ and $15^{\text {th }}$ degrees of longitude East, in the Far North, Cameroon (Figure 1). It is limited to the North, by the Logone and Chari division, to the North-east by the Diamaré division, to the West by the Mayo-Kani division and to the East and South by the Republic of Chad. It covers an area of $5.300 \mathrm{~km}^{2}$ with a cosmopolitan population estimated at more than 600000 souls, with an average density of 142 inhabitants per $\mathrm{km}^{2}$. The climate is of the Sudano-Sahelian type, with a long dry season (September-May) and a short rainy season (June-August). Its relief consists of a vast savannah spread over a uniform plain. Mayo-Danay is practically the only division in Cameroon where no mountain rises on the horizon, offering you a panoramic view of a landscape of steppe and shrub savannah. Several ethnic groups live in peace and harmony and share the department. They are among others, the Massa, the Toupouri, the Musgum, the Mousey, the Peulhs, the Kanuri and the Kera.

There are four types of soil in the Mayo-Danay division [29]:

1. Clay soils (or vertisol), locally known as "Karals";

2. Ferruginous soils (or sesquioxide soils) with little or no leaching;

3. Halomorphic soils these types of soils are generally uncultivated and known locally as "harde";

4. Hydromorphic soils.

The vegetation is dominated by species like Terminalia avicennioides, Guiera senegalensis, Detarium senegalensis, Faidherbia albida, Strychnos spinosa, Hyphaene thebaica, Prosopis africana and Parkia biglobosa. The type of vegetation is either a shrub savannah or a forest savannah, as in the Kalfou reserve. The sandy-clay bulges of MayoGuerléo (Kaïkaï subdivision), Logone (Gobo subdivision) and Northern Toupouri (Subdivision of Tchatibali, Doukoulou, Datchéka, and Kalfou) are occupied by a more or less shrubby savannah based on : Faidherbia albida, Balanites aegyptiaca, Ziziphus mauritiana, Hyphaene thebaica, Capparis corymbosa, Calotropis procera, Ziziphus spina-christi, Cissus quadrangularis. The grass carpet is most often formed by Aristida hordacea, Aristida adscensionis and Schoenefeldia gracilis. In the Kalfou reserve, we find in the interdunes, more or less flooded in the rainy season with a grass vegetation of Andropogon sp. with frequently a tree layer of Terminalia macroptera, Bauhinia reticulata, Gardenia ternifolia, Combretum glutinosum and Mitragyna inermis, Prosopis africana. In the great clay plains of the division, there is often a tree savannah made from Acacia seyal. In the plains north of Yagoua, between Logone and Guerleo, and in the center-south of the department, where the flooding is very long, dominate grassland savannas with Hyparrhenia rufa, Cympobogon giganteus, Sporobolus pyramidalis and Echinochloa sp. In the north of Lake Fianga, in the plains that remain flooded 
even in the dry season, there is little more than less or less floating vegetation of Echinochloa stagnina [29].

The climatic conditions and the relief arrangements of the region are favorable for agriculture. Food crops : cereals, especially pearl millet (red millet), dry season muskuari
(Sorghum sp.), corn and rice ; Oilseeds, in this case peanuts, voandzou, cowpeas; Tubers, more precisely, cassava ; Legumes (tomatoes, salads, carrots, etc.) ; Fruit trees (guava trees, mango trees, cashew trees, etc.) ; cash crops are cotton and rice [30].

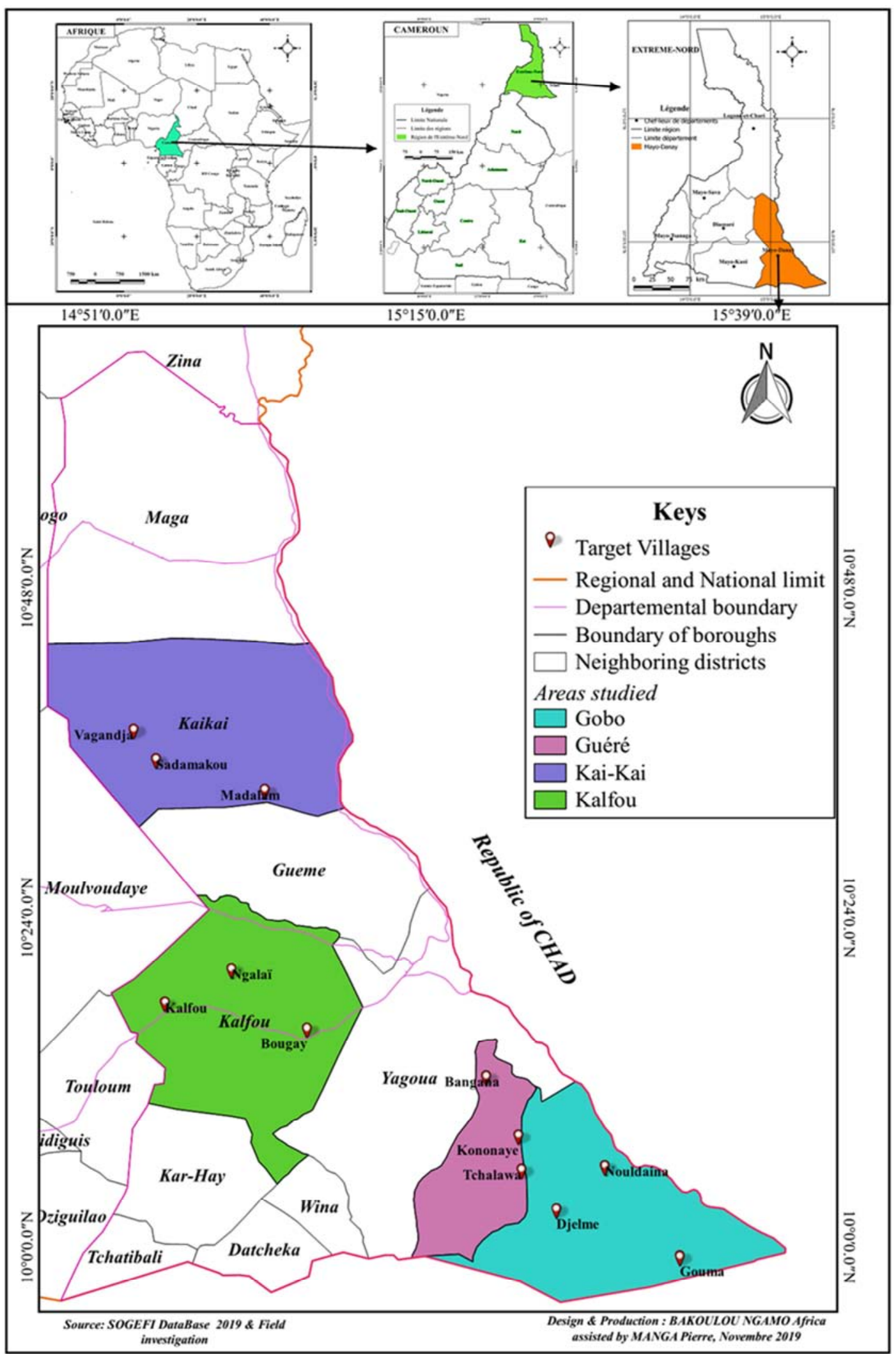

Figure 1. Location map of the study area. 


\subsection{Data Collection}

Three villages were selected for each of the four subdivisions, for a total of 12 villages. In the subdivision of Gobo we have: Djelme, Gouma and Nouldaina. For the subdivision of Guere the villages are: Bangana, Kononaye and Tchalawa. In the subdivision of Kalfou we have as villages: central Kalfou, Bougaye and Ngalaï. The villages: Madalam, Sadamakou and Vagandja are in the subdivision of Kaikai. The choice is justified by the presence of plant formations and the importance of anthropogenic activities linked especially to slash and burn agriculture.

The transect method [31] was used for the floristic surveys of our study area. We inventoried a total of 36 transects (i.e. 03 transects per site). The technique consists in delimiting a plot of $500 \mathrm{~m}$ of legnthand $20 \mathrm{~m}$ of width with an interval of $50 \mathrm{~m}$ between the transects. On each previously delimited transect, the floristic list was established and a few dendrometric parameters were measured. The measurements of these dendrometric parameters were brought to the heights of the trees and the diameters of the tassel were determined with a batten or a graduated pole $5 \mathrm{~m}$ long and the circumference (circumference at breast height $1.30 \mathrm{~m}$ ) with a measuring tape [32]. For trees with a height less than $1.30 \mathrm{~m}$, we measured at $0.3 \mathrm{~m}$ in soil height [33]. The identification of the species were done basing on the flora of West Africa [34].

\subsection{Data Analysis}

The data collected in the field from June to October 2019, were subjected to statistical processing. The Shannon index [35] expresses the relative importance of the species of a given environment. The index is minimum when all the individuals belong to the same species. It is maximum when each individual represents a distinct species [36]. It is given by the following relation:

ISH $=-\Sigma\left(n_{i} / N\right) \log 2\left(n_{i} / N\right)$, with $n_{i}=$ number of species $i$,
$N=$ number of all species; it is expressed in bits.

The regularity index or the Evenness of Pielou [37] is the ratio between the observed diversity and the maximum possible diversity of the number of species $(\mathrm{N})$. It ranges from 0 to 1 and tends to 1 when each of the species is represented by the same number of individuals [38]. Its value is obtained using the following formula:

$$
\mathrm{EQ}=\mathrm{ISH} / \log 2 \mathrm{~N}
$$

The ecological importance of the species (IVI) [39] has been calculated. The ecological importance or importance value index (IVI) is given by the following relation:

$$
\begin{gathered}
\text { IVI = Relative density (Dre) }+ \text { Relative dominance }(\mathrm{De})+\text { Relative frequency }(\mathrm{Fre}) \\
\text { FIV = family relative diversity (Dire) }+ \text { relative density (Dre) }+ \text { relative dominance (De) }
\end{gathered}
$$

The centesimal relative density (Dre) corresponds to the proportion of individuals of one species (Ni) compared to individuals of all species $(\mathrm{N})$. Family relative diversity $($ Dire $)=$ (number of species in a family/total number of species) $\times 100$. Relative dominance (De) is the area occupied by a species (by its basal area (Sti) or its overlap) compared to the area occupied by all the species in the sample $(\mathrm{St})$. The relative frequency $(\mathrm{Fr})$ designates the distribution of a species in relation to the distribution of all the species in the sample. It is given by the ratio between the centesimal frequency of presence of the species $i$ and the sum of the centesimal frequencies of presence of all the species in the sample $(\mathrm{F})$. Density $(\mathrm{N})$ is the number of individuals per unit area. It is expressed in number of individuals / ha. It is obtained by the ratio of the total number of individuals in the sample (n) by the area sampled (S).

$\mathrm{N}=\frac{\mathrm{n}}{\mathrm{s}}$ where $\mathrm{n}=$ total number of individuals inventoried at each site ;

$\mathrm{S}=$ total area sampled from the site in ha.

The basal area (St) or basal covering, is the sum of the basal areas of all individuals whose basal circumference (C) is greater than or equal to $0.3 \mathrm{~m}$. This basal area can be estimated by considering that the sections of the stems are circular. It is expressed per unit area $\left(\mathrm{m}^{2} \cdot \mathrm{ha}^{-1}\right)$ and is calculated as described by [40].

$\mathrm{St}=\sum \frac{C^{2}}{4 \pi}$ where $\mathrm{St}=$ basal area expressed in $\mathrm{m}^{2} \cdot \mathrm{ha}^{-1} ; \mathrm{C}=$ circumference at $0.3 \mathrm{~m}$ from the ground of the individuals measured.

For the different plant formations identified, the diversity indices and dendrometric parameters such as density, basal area, diameter at breast height (Dbh) and height were subjected to analysis of variance (ANOVA) to test whether the differences between the plant formations of villages and districts are significant and Fisher's LSD test to compare the means.

Table 1. The overall richness of the different sites in the study area.

\begin{tabular}{lllll}
\hline Sub-divisions & Villages & Species & Genus & Family \\
\hline & Djelme & 17.00 & 16.00 & 12.00 \\
& Gouma & 13.00 & 11.00 & 8.00 \\
Gobo & Nouldaina & 24.00 & 22.00 & 17.00 \\
& & 35 & 31 & 21 \\
& Bangana & 9.00 & 7.00 & 6.00 \\
& Kononaye & 11.00 & 8.00 & 6.00 \\
Guéré & Tchalawa & 16.00 & 13.00 & 10.00 \\
& & 19 & 15 & 10 \\
& Madalam & 15.00 & 12.00 & 9.00 \\
& Sadamakou & 14.00 & 13.00 & 8.00 \\
Kaïkaï & Vagandja & 18.00 & 15.00 & 11.00 \\
& & 26 & 22 & 14 \\
& Bougaye & 19.00 & 16.00 & 13.00 \\
& Kalfou-center & 30.00 & 21.00 & 12.00 \\
Kalfou & Ngalaï & 15.00 & 11.00 & 9.00 \\
Total & & 40 & 28 & 19 \\
\hline
\end{tabular}




\section{Results}

\subsection{Floristic Composition}

The total specific richness is 57 species belonging to 43 genera and 26 families out of 36 surveys that were carried out in 12 villages in the 04 sub-divisions of the Mayo-Dany division (Table 1). The village with the highest number of species is Kalfou center ( 30 species) and the village with the lowest number is Bangana (09 species) (Table 1). The sub- division with the highest number of species is Kalfou (40 species) while Guere is the sub-division with the smallest population (19 species). The largest number of families is observed in the village of Nouldaina and the Gobo subdivision, on the other hand, the villages of Bangana and Kononaye and the Guere sub-division have the smallest number of families. Amongst the 57 species recorded, 28 species were scarce in the area (Table 2).

Table 2. Lists of rare woody species identified.

\begin{tabular}{|c|c|c|c|c|c|c|c|c|c|c|c|c|c|}
\hline Familly & Species & 1 & 2 & 3 & 4 & 5 & 6 & 7 & 8 & 9 & 10 & 11 & 12 \\
\hline Fabaceae & Amblygonocarpus adongensis (Oliv.) Exell et Torre & & & & & & & & & & & + & \\
\hline Caesalpiniaceae & Bauhinia rufescens Lam. & & & & & & & + & + & & & & \\
\hline Bombacaceae & Bombax costatum Pellegr. et Vuillet & & & & & & & & & & & & \\
\hline Capparaceae & Boscia senegalensis (Pers.) Lam. ex Poir. & & & + & & & + & & & & & & \\
\hline Euphorbiaceae & Bridelia scleroneura Müll. Arg. & & + & + & & & & & & & & & \\
\hline Capparaceae & Cadaba farinose Forssk. & & & & & & & & & & & + & \\
\hline Ulmaceae & Celtis integrifolia Lam. & & & & & & & & + & & & & \\
\hline Caesalpiniaceae & Daniellia oliveri(Rolfe) Hutch. et Dalz. & & & & & & & & & & & + & \\
\hline Ebenaceae & Diospyros mespiliformis Hochst. ex A. Rich. & & & & & & & & & & & + & \\
\hline Moraceae & Ficus platyphylla Del. & & & & & & & & & & + & + & \\
\hline Moraceae & Ficus sycomorus (Miq.) C. C. Berg & & + & & & & & & & & & + & \\
\hline Hymenocardiaceae & Hymenocardia acida Tul. & & & & & & + & & & & & & \\
\hline Anacardiaceae & Lannea acidaA. Rich. & & & + & & & & & & & & & \\
\hline Celastraceae & Maytenus senegalensis (Lam.) Exell & & & + & & + & + & & & & & & \\
\hline Sapotaceae & Pachystela brevipes(Baker f.) T. D. Penn. & & & + & & & & & & & & & + \\
\hline Mimosaceae & Parkia biglobosa(Jacq.) R. Br. ex G. Don & & & + & & & & & & & & & \\
\hline Caesalpiniaceae & Piliostigma thonningii (Schumach.) Milne-Redh. & & & & & + & + & & & & & & \\
\hline Mimosaceae & Prosopis africana (Guill. et Perr.) Taub. & + & + & + & & & + & & + & & + & & \\
\hline Meliaceae & Pseudocedrela kotschyi (Schweinf.) Harms & & + & + & & & & & & & & & \\
\hline Fabaceae & Pterocarpus erinaceusPoir. & & + & & & & & & & & & & \\
\hline Polygalaceae & Securidaca longipedunculata Fres. & & + & & & & & & & & & & \\
\hline Bignoniaceae & Stereospermum kunthianum Cham. & + & & & & & & & & & + & & \\
\hline Loganiaceae & Strychnos spinosa Lam. & + & + & & & & & & + & & & & \\
\hline Caesalpiniaceae & Tamarindus indica $\mathrm{L}$. & & + & & & & & & + & + & & + & \\
\hline Combretaceae & Terminalia macroptera Guill. et Perr. & & + & & & + & + & & & & & + & \\
\hline Sapotaceae & Vitellaria paradoxa Gaertn. f. & & + & & & & & & & & & & \\
\hline
\end{tabular}

$(1=$ Djelme; $2=$ Gouma; $3=$ Nouldaina; $4=$ Bangana; $5=$ Kononaye; $6=$ Tchalawa; $7=$ Madalam; $8=$ Sadamakou; $9=$ Vagandja; $10=$ Bougaye; $11=$ Kalfou-center; 12 = Ngalai; $+=$ presence)

The specific diversity in Mayo-Danay varies according to the sites. According to the villages, the Shannon diversity indices vary from 2.93 bits in the village of Bangana to 4.82 bits in the village of Kalfou-center (Table 3). The Kalfou sub-division presents an index of Shannon diversity more high by all the subdivision, the Guere subdivisionis the one with the lowest value in the Shannon diversity index (Table 4). The analysis of variance reveals a non-significant difference between the villages $(p=0.1519>0.05)$ (Table 3$)$; on the other hand, there is a very highly significant difference between the sub-divisions $(p=0.0004<0.05)$ (Table 4). Pielou's fairness ranges from 0.45 in the village of bangana to 0.67 in the village of kalfou-center. Piélou's fairness is higher in the villages of Kalfou-center and Nouldaina. On the other hand, the low values are observed in the villages of Bangana and Kononaye (Table 3). The analysis of variance shows a non-significant difference between the villages $(\mathrm{p}=0.8419>0.05)($ Table 3$)$ and also between the subdivisions $(\mathrm{p}=0.5517>0.05)($ Table 4$)$. For the entire woody stand in our study area, the Shannon index is 3.74 and the Pielou's Evenness is 0.57 (Table 4).

Table 3. Diversity parameters per village.

\begin{tabular}{llll}
\hline Subdivisions & Villages & ISH (bits) & EQ \\
\hline Djelme & 3.59 & 0.57 \\
Gouma & 3.28 & 0.61 \\
Nouldaina & 4.33 & 0.63 \\
Bangana & 2.93 & 0.45 \\
Kononaye & 3.21 & 0.52 \\
Tchalawa & 3.62 & 0.53 \\
Madalam & 3.62 & 0.56 \\
Sadamakou & 3.90 & 0.60 \\
Vagandja & 3.91 & 0.56 \\
Bougaye & 3.96 & 0.58 \\
Kalfou-center & 4.82 & 0.67 \\
Ngalaï & 3.69 & 0.54 \\
ANOVA & $\mathrm{F}=2.04$ & $\mathrm{~F}=0.17$ \\
& $\mathrm{P}=0.1519$ & $\mathrm{P}=0.8419$ \\
& $\mathrm{~ns}$ & $\mathrm{~ns}$ \\
\hline
\end{tabular}

$\mathrm{ISH}=$ Shannon index, EQ $=$ Pietlou equitability, $\mathrm{D}=$ Simpson index, Non-significant difference (ns), significant difference at: $*=0.05 ; * *=0.01 ; * *=0.001$. 
Table 4. Diversity parameters per district.

\begin{tabular}{lll}
\hline Subdivisions & ISH (bits) & EQ \\
\hline Gobo & 3.73 & 0.60 \\
Guéré & 3.25 & 0.50 \\
Kaïkaï & 3.81 & 0.57 \\
Kalfou & 4.16 & 0.59 \\
Woody stand & 3,74 & 0,57 \\
ANOVA & $\mathrm{F}=8.83$ & $\mathrm{~F}=0.72$ \\
& $\mathrm{P}=0.0004$ & $\mathrm{P}=0.5517$ \\
& $* * *$ & $\mathrm{Ns}$ \\
\hline
\end{tabular}

$\mathrm{ISH}=$ Shannon index, EQ $=$ Pietlou equitability,

Non-significant difference (ns), significant difference at: $*=0.05 ; * *=0.01 ; * * *=0.001$.

The most important species in terms of value of ecological importance (IVI) and which are found in all the sites of our study area were respectively Balanites aegyptiaca (60.21 from Sadamakou), Anogeissus leiocarpus (52.15 from Ngalai), Acacia seyal (49.59 from Bangana) (Table 5). The importance value index varies from one site to other. It varies between 77.98 (Piliostigma reticulatum from Kononaye) to 10.44 (Terminalia avicennioides from Gouma) (Table 5). The importance value indexaccording to the sub-divisions shows that in the Gobo subdivision these were the species like Terminalia macroptera (71.30) and Piliostigma reticulatum (63.89) from the village Gouma, and then Detarium microcarpum (63.37) from the village Djelme which are respectively the most ecologically important of the species unlike the Acacia seyal (10.44) from the village of Gouma with the lowest value (Table 5). In the Guere sub-division we have Piliostigma reticulatum (77.98) from the village Kononaye, Acacia sieberiana (54.31) and Balanites aegyptiaca (53.47) from the village Bangana are the species which have the highest values in ecological value index unlike the species Acacia seyal (11.75) from the village Tchalawa (Table 5). As for the Kaikai subdivision the species with the most important values in IVI are Balanites aegyptiaca (60.21) of the village Sadamakou, Hexalobus monopetalus (46.99) and Anogeissus leiocarpus (42.94) of the village Madalam respectively, but the species Dalbergia melanoxylon (10.60) of the village Vagandja the presents the lowest value (Table 5). At the end as regards the Kalfou subdivision we note that the species such as Balanites aegyptiaca (56.78) and Acacia seyal (48.39) of the village Bougaye then Anogeissus leiocarpus (52.15) of the village Ngalai have very strong values in IVI on the other hand the lowest value is noted at Sclerocarya birrea (12.28) (Table 5).

Table 5. Species with Significance of Value Indices $\geq 10$ according to the sites.

\begin{tabular}{|c|c|c|c|c|c|c|}
\hline Sub-divisions & Villages & Species & Dre (\%) & $\operatorname{FrRe}(\%)$ & De $(\%)$ & IVIE (\%) \\
\hline & Djelme & Detarium microcarpum Guill. \& Perr. & 27.01 & 8.11 & 28.25 & 63.37 \\
\hline & & Hexalobus monopetalus (A. Rich.) Engl. \& Diels & 30.33 & 8.11 & 0.97 & 39.41 \\
\hline & & Pachystela brevipes (Baker) Engl. & 1.42 & 5.41 & 28.62 & 35.45 \\
\hline & & Combretum adenogonium Steud. ex. A. Rich. & 5.69 & 8.11 & 5.11 & 18.90 \\
\hline & & Acacia seyal Del. & 6.16 & 5.41 & 6.45 & 18.02 \\
\hline & & Anogeissus leiocarpus (DC.) Guill. \& Perr. & 5.21 & 5.41 & 5.69 & 16.31 \\
\hline & & Prosopis africana (Guill. \& Perr.) Taub. & 3.32 & 5.41 & 3.61 & 12.33 \\
\hline & & Sclerocarya birrea (A. Rich.) Hochst. & 3.79 & 8.11 & 4.19 & 16.09 \\
\hline & & Piliostigma reticulatum (DC.) Hochst. & 2.37 & 8,11 & 2,79 & 13.27 \\
\hline & & Senna singueana (Del.) Lock & 3.79 & 5.41 & 3.87 & 13.07 \\
\hline & & Balanites aegyptiaca (L.) Del. & 2.37 & 5.41 & 3.16 & 10.93 \\
\hline & Gouma & Terminalia macroptera Guill. \& Perr. & 34.45 & 23.81 & 13.04 & 71.30 \\
\hline \multirow[t]{23}{*}{ Gobo } & & Piliostigma reticulatum (DC.) Hochst. & 25.68 & 25.17 & 13.04 & 63.89 \\
\hline & & Combretum collinum Fresen. & 11.51 & 12.93 & 13.04 & 37.48 \\
\hline & & Pseudocedrela kotschyi (Schweinf.) Harms & 3.83 & 13.61 & 8.70 & 26.13 \\
\hline & & Combretum adenogonium Steud. ex. A. Rich. & 8.57 & 8.84 & 8.70 & 26.11 \\
\hline & & Prosopis africana (Guill. \& Perr.) Taub. & 3.93 & 4.76 & 8.70 & 17.38 \\
\hline & & Balanites aegyptiaca (L.) Del. & 3.93 & 2.72 & 4.35 & 10.99 \\
\hline & & Acacia seyal Del. & 3.37 & 2.72 & 4.35 & 10.44 \\
\hline & Nouldaina & Combretum adenogonium Steud. ex. A. Rich. & 18.38 & 6.25 & 17.57 & 42.19 \\
\hline & & Sclerocarya birrea (A. Rich.) Hochst. & 11.54 & 6.25 & 15.34 & 33.13 \\
\hline & & Sterculia setigera Del. & 6.41 & 4.17 & 7.97 & 18.55 \\
\hline & & Piliostigma reticulatum (DC.) Hochst. & 8,12 & 4.17 & 6.23 & 18.52 \\
\hline & & Maytenus senegalensis (Lam.) Exell & 4.70 & 8.33 & 4.35 & 17.39 \\
\hline & & Pterocarpus erinaceus Poir. & 2.14 & 10.42 & 3.10 & 15.65 \\
\hline & & Anogeissus leiocarpus (DC.) Guill. \& Perr. & 5.56 & 4.17 & 5.44 & 15.16 \\
\hline & & Bridelia scleroneura Müll. Arg. & 5.56 & 4.17 & 5.40 & 15.12 \\
\hline & & Pseudocedrela kotschyi (Schweinf.) Harms & 5.98 & 6.25 & 1.90 & 14.13 \\
\hline & & Prosopis africana (Guill. \& Perr.) Taub. & 5.13 & 4.17 & 4.43 & 13.73 \\
\hline & & Balanites aegyptiaca (L.) Del. & 3.42 & 4.17 & 4.82 & 12.40 \\
\hline & & Terminalia avicennioides Guill. \& Perr. & 3.85 & 4.17 & 4.39 & 12.40 \\
\hline & & Combretum glutinosum Perr. ex DC. & 3.42 & 4.17 & 3.99 & 11.57 \\
\hline & & Combretum collinum Fresen. & 2.14 & 6.25 & 2.63 & 11.02 \\
\hline & Bangana & Acacia sieberiana DC. & 16.10 & 15.79 & 22.42 & 54.31 \\
\hline & & Balanites aegyptiaca (L.) Del. & 18.64 & 15.79 & 19.03 & 53.47 \\
\hline
\end{tabular}




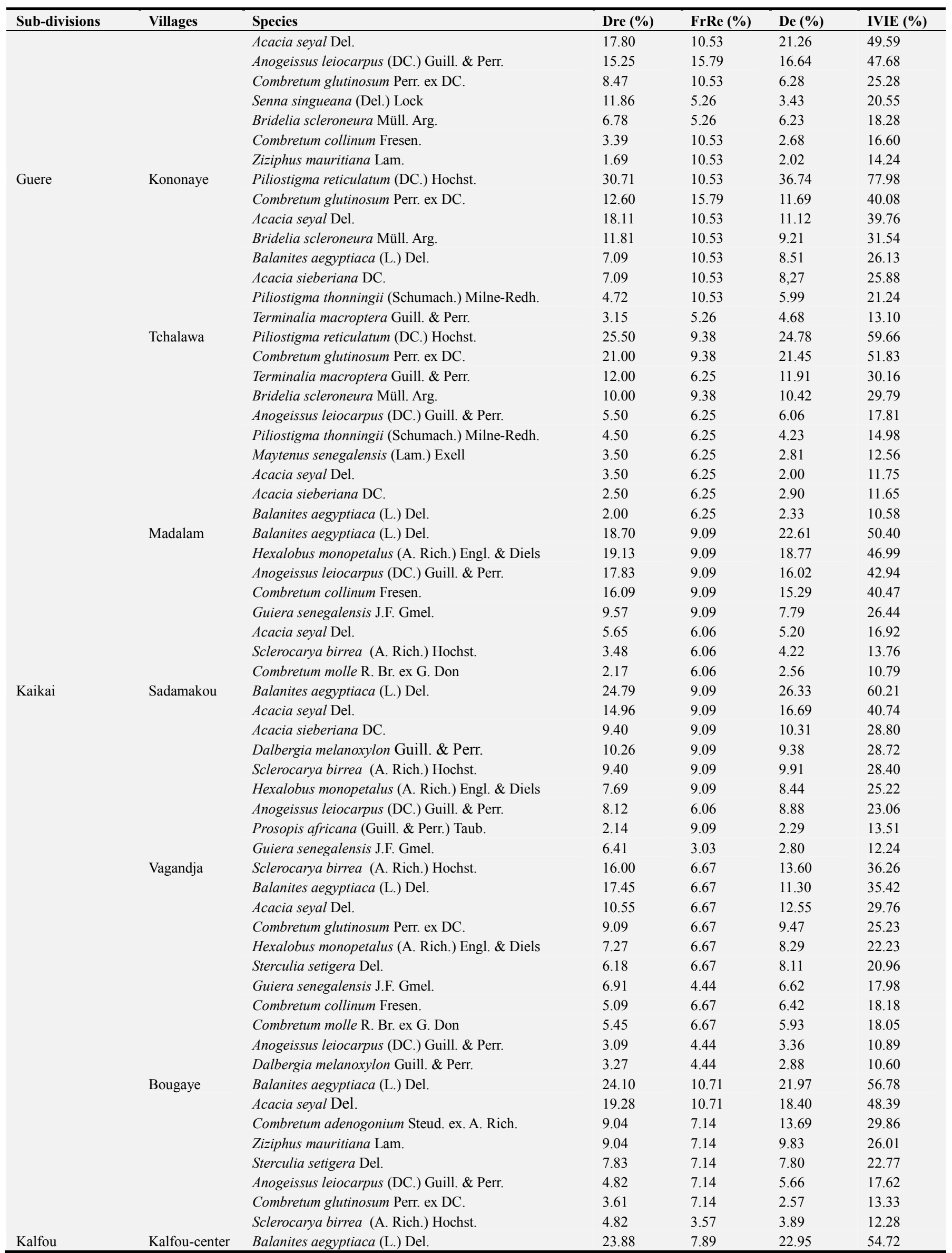




\begin{tabular}{|c|c|c|c|c|c|c|}
\hline Sub-divisions & Villages & Species & Dre (\%) & $\operatorname{FrRe}(\%)$ & De $(\%)$ & IVIE (\%) \\
\hline & \multirow{15}{*}{ Ngalai } & Ziziphus mauritiana Lam. & 16.92 & 5.26 & 18.08 & 40.26 \\
\hline & & Sclerocarya birrea (A. Rich.) Hochst. & 8.46 & 5.26 & 8.62 & 22.34 \\
\hline & & Anogeissus leiocarpus (DC.) Guill. \& Perr. & 7.46 & 5.26 & 6.91 & 19.64 \\
\hline & & Sterculia setigera Del. & 5.47 & 5.26 & 6.40 & 17.14 \\
\hline & & Acacia seyal Del. & 5.47 & 5.26 & 4.21 & 14.95 \\
\hline & & Combretum glutinosum Perr. ex DC. & 4.98 & 5.26 & 5.50 & 15.74 \\
\hline & & Anogeissus leiocarpus (DC.) Guill. \& Perr. & 19.62 & 10.71 & 21.82 & 52.15 \\
\hline & & Balanites aegyptiaca (L.) Del. & 17.72 & 7.14 & 15.67 & 40.53 \\
\hline & & Sclerocarya birrea (A. Rich.) Hochst. & 13.29 & 7.14 & 13.06 & 33.50 \\
\hline & & Ziziphus mauritiana Lam. & 10.13 & 7.14 & 10.63 & 27.90 \\
\hline & & Sterculia setigera Del. & 8.23 & 7.14 & 8.44 & 23.82 \\
\hline & & Terminalia avicennioides Guill. \& Perr. & 5.06 & 7.14 & 6.04 & 18.24 \\
\hline & & Combretum molle R. Br. ex G. Don & 5.06 & 7.14 & 4.22 & 16.43 \\
\hline & & Guiera senegalensis J.F. Gmel. & 1.90 & 10.71 & 1.39 & 14.00 \\
\hline & & Acacia seyal Del. & 3.16 & 3.57 & 4.22 & 10.96 \\
\hline
\end{tabular}

$\mathrm{De}=$ relative dominance, Dre $=$ relative density, Fre $=$ relative frequency and $\mathrm{IVI}=$ importance value index.

Table 6 presents families of value of importance (FIV). We note that the families most strongly represented in terms of value of importance of our study area are respectively the Combretaceae (IVF $=99.33$ in Gouma in the Gobo subdivision), Mimosaceae (FIV $=95.78$ in Kalfou-center in the Kalfou sub-division) and Caesalpiniaceae (FIV $=89.71$ in
Djelme in the Gobo sub-division). On the other hand, the most underrepresented families are respectively the Moraceae (FIV $=10.23$ at Bougaye in the district of Kalfou), Balanitaceae $((\mathrm{FIV}=10.58$ at Tchalawa in the Guere subdivision) and Sapotaceae (FIV $=10.96$ in Ngalai in the Kalfou sub-division) (Table 6).

Table 6. Families with Significance Values $\geq 10$ depending on the site.

\begin{tabular}{|c|c|c|c|c|c|c|}
\hline Sub-divisions & Villages & Families & Dre & Dire & De & FIV \\
\hline \multirow{17}{*}{ Gobo } & \multirow{6}{*}{ Djelme } & Caesalpiniaceae & 33.18 & 21.62 & 34.91 & 89.71 \\
\hline & & Combretaceae & 12.32 & 18.92 & 12.09 & 43.33 \\
\hline & & Mimosaceae & 12.80 & 16.22 & 13.67 & 42.69 \\
\hline & & Sapotaceae & 1.42 & 5.41 & 28.62 & 35.45 \\
\hline & & Anacardiaceae & 3.79 & 8.11 & 4.19 & 16.09 \\
\hline & & Balanitaceae & 2.37 & 5.41 & 3.16 & 10.93 \\
\hline & \multirow{6}{*}{ Gouma } & Caesalpiniaceae & 26.86 & 25.85 & 17.39 & 70.10 \\
\hline & & Anacardiaceae & 7.29 & 11.56 & 8.70 & 27.56 \\
\hline & & Meliaceae & 3.83 & 13.61 & 8.70 & 26.13 \\
\hline & & Mimosaceae & 3.93 & 4.76 & 8.70 & 17.38 \\
\hline & & Olacaceae & 2.58 & 3.40 & 8.70 & 14.68 \\
\hline & & Balanitaceae & 5.85 & 2.68 & 4.35 & 12.88 \\
\hline & \multirow{5}{*}{ Nouldaina } & Combretaceae & 33.33 & 25.00 & 34.01 & 92.34 \\
\hline & & Anacardiaceae & 14.96 & 8.33 & 18.42 & 41.71 \\
\hline & & Sterculiaceae & 6.41 & 4.17 & 7.97 & 18.55 \\
\hline & & Mimosaceae & 5.56 & 6.25 & 5.51 & 17.32 \\
\hline & & Fabaceae & 2.14 & 10.42 & 3.10 & 15.65 \\
\hline \multirow{16}{*}{ Guéré } & \multirow{6}{*}{ Bangana } & Mimosaceae & 18.90 & 25.68 & 18.32 & 62.90 \\
\hline & & Combretaceae & 17.12 & 15.60 & 26.84 & 59.56 \\
\hline & & Balanitaceae & 18.64 & 19.03 & 15.79 & 53.47 \\
\hline & & Euphorbiaceae & 6.78 & 6.23 & 5.26 & 18.28 \\
\hline & & Caesalpiniaceae & 11.86 & 3.43 & 5.26 & 20.55 \\
\hline & & Rhamnaceae & 1.69 & 2.02 & 10.53 & 14.24 \\
\hline & \multirow{5}{*}{ Kononaye } & Caesalpiniaceae & 35.43 & 21.05 & 32.73 & 89.21 \\
\hline & & Mimosaceae & 26.77 & 26.32 & 21.38 & 74.47 \\
\hline & & Combretaceae & 17.32 & 26.32 & 17.68 & 61.32 \\
\hline & & Euphorbiaceae & 11.81 & 10.53 & 9.21 & 31.54 \\
\hline & & Balanitaceae & 7.09 & 10.53 & 8.51 & 26.13 \\
\hline & \multirow{5}{*}{ Tchalawa } & Combretaceae & 19.50 & 28.13 & 33.50 & 81.12 \\
\hline & & Euphorbiaceae & 10.00 & 9.38 & 10.42 & 29.79 \\
\hline & & Celastraceae & 3.50 & 6.25 & 2.81 & 12.56 \\
\hline & & Rubiaceae & 1.50 & 6.25 & 3.54 & 11.29 \\
\hline & & Balanitaceae & 2.00 & 6.25 & 2.33 & 10.58 \\
\hline
\end{tabular}




\begin{tabular}{|c|c|c|c|c|c|c|}
\hline Sub-divisions & Villages & Families & Dre & Dire & De & FIV \\
\hline \multirow{18}{*}{ Kaikai } & \multirow{5}{*}{ Madalam } & Combretaceae & 19.96 & 34.39 & 42.77 & 97.12 \\
\hline & & Annonaceae & 22.61 & 15.15 & 22.99 & 60.76 \\
\hline & & Balanitaceae & 18.70 & 9.09 & 22.61 & 50.40 \\
\hline & & Mimosaceae & 6.96 & 12.12 & 6.61 & 25.69 \\
\hline & & Rhamnaceae & 2.17 & 12.12 & 2.37 & 16.66 \\
\hline & \multirow{7}{*}{ Sadamakou } & Mimosaceae & 28.63 & 33.33 & 30.32 & 92.28 \\
\hline & & Combretaceae & 14.53 & 9.09 & 11.68 & 35.30 \\
\hline & & Anacardiaceae & 9.40 & 9.09 & 9.91 & 28.40 \\
\hline & & Balanitaceae & 24.79 & 9.09 & 26.33 & 60.21 \\
\hline & & Fabaceae & 10.26 & 9.09 & 9.38 & 28.72 \\
\hline & & Annonaceae & 7.69 & 9.09 & 8.44 & 25.22 \\
\hline & & Caesalpiniaceae & 2.56 & 12.12 & 2.08 & 16.76 \\
\hline & \multirow{8}{*}{ Vagandja } & Combretaceae & 26.55 & 24.44 & 28.44 & 79.43 \\
\hline & & Mimosaceae & 13.82 & 13.33 & 16.86 & 44.01 \\
\hline & & Balanitaceae & 17.09 & 11.11 & 14.70 & 42.90 \\
\hline & & Anacardiaceae & 7.27 & 6.67 & 8.29 & 22.23 \\
\hline & & Sterculiaceae & 6.18 & 6.67 & 8.11 & 20.96 \\
\hline & & Caesalpiniaceae & 2.91 & 8.89 & 3.10 & 14.90 \\
\hline \multirow{24}{*}{ Kalfou } & & Euphorbiaceae & 2.18 & 8.89 & 2.04 & 13.11 \\
\hline & & Fabaceae & 3.27 & 4.44 & 2.88 & 10.60 \\
\hline & \multirow{8}{*}{ Bougaye } & Combretaceae & 18.67 & 25.00 & 23.23 & 66.90 \\
\hline & & Mimosaceae & 22.29 & 17.86 & 20.77 & 60.92 \\
\hline & & Balanitaceae & 24.10 & 10.71 & 21.97 & 56.78 \\
\hline & & Rhamnaceae & 9.04 & 7.14 & 9.83 & 26.01 \\
\hline & & Sterculiaceae & 7.83 & 7.14 & 7.80 & 22.77 \\
\hline & & Anacardiaceae & 4.82 & 3.57 & 3.89 & 12.28 \\
\hline & & Rubiaceae & 3.61 & 3.57 & 3.77 & 10.96 \\
\hline & & Moraceae & 1.20 & 7.14 & 1.89 & 10.23 \\
\hline & \multirow{7}{*}{ Kalfou-center } & Mimosaceae & 29.30 & 28.95 & 37.53 & 95.78 \\
\hline & & Combretaceae & 16.42 & 21.05 & 14.82 & 52.29 \\
\hline & & Rhamnaceae & 16.92 & 5.26 & 18.08 & 40.26 \\
\hline & & Balanitaceae & 9.45 & 7.89 & 10.34 & 27.69 \\
\hline & & Anacardiaceae & 5.47 & 5.26 & 6.40 & 17.14 \\
\hline & & Moraceae & 3.98 & 7.89 & 3.97 & 15.84 \\
\hline & & Caesalpiniaceae & 2.49 & 7.89 & 2.29 & 12.67 \\
\hline & \multirow{7}{*}{ Ngalai } & Combretaceae & 22.71 & 53.57 & 22.40 & 98.68 \\
\hline & & Balanitaceae & 17.72 & 7.14 & 15.67 & 40.53 \\
\hline & & Anacardiaceae & 13.29 & 7.14 & 13.06 & 33.50 \\
\hline & & Mimosaceae & 8.23 & 10.71 & 9.21 & 28.15 \\
\hline & & Rhamnaceae & 10.13 & 7.14 & 10.63 & 27.90 \\
\hline & & Sterculiaceae & 8.23 & 7.14 & 8.44 & 23.82 \\
\hline & & Sapotaceae & 3.16 & 3.57 & 4.22 & 10.96 \\
\hline
\end{tabular}

$\mathrm{De}=$ relative dominance, Dre $=$ relative density, Dire = relative diversity and FIV = Family of importance value.

Table 7. Dendrometric parameters per village.

\begin{tabular}{lll}
\hline Villages & $\mathbf{N}(\mathbf{S t e m s} / \mathbf{h a})$ & $\mathbf{S t}\left(\mathbf{m}^{\mathbf{2}} / \mathbf{h a}\right)$ \\
\hline Djelme & $28.89 \pm 4.24^{\mathrm{de}}$ & $77.37 \pm 25.47^{\mathrm{abc}}$ \\
Gouma & $24.78 \pm 6.00^{\text {def }}$ & $54.97 \pm 33.72^{\mathrm{abc}}$ \\
Nouldaina & $40.22 \pm 9.26^{\mathrm{bc}}$ & $85.33 \pm 40.46^{\mathrm{abc}}$ \\
Bangana & $14.89 \pm 3.27^{\mathrm{f}}$ & $27.43 \pm 2.86^{\mathrm{bc}}$ \\
Kononaye & $24.11 \pm 4.22^{\mathrm{ef}}$ & $23.01 \pm 13.17^{\mathrm{c}}$ \\
Tchalawa & $35.11 \pm 2.91^{\mathrm{bcde}}$ & $61.76 \pm 13.13^{\mathrm{abc}}$ \\
Madalam & $32.22 \pm 3.72^{\mathrm{bcde}}$ & $105.82 \pm 80.75^{\mathrm{ab}}$ \\
Sadamakou & $36.00 \pm 5.10^{\mathrm{bcde}}$ & $97.77 \pm 30.12^{\mathrm{abc}}$ \\
Vagandja & $41.67 \pm 4.92^{\mathrm{b}}$ & $109.64 \pm 22.93^{\mathrm{a}}$ \\
Bougaye & $38.56 \pm 3.65^{\mathrm{bc}}$ & $101.89 \pm 55.59^{\mathrm{abc}}$ \\
Kalfou-center & $55.44 \pm 10.49^{\mathrm{a}}$ & $69.49 \pm 32.89^{\mathrm{abc}}$ \\
Ngalai & $39.89 \pm 3.70^{\mathrm{bc}}$ & $93.34 \pm 51.27^{\mathrm{abc}}$ \\
ANOVA & $\mathrm{F}=7.23$ & $\mathrm{~F}=0.91$ \\
& $\mathrm{P}=0.0035$ & $\mathrm{P}=0.4147$ \\
\hline
\end{tabular}

$\mathrm{N}=$ density, $\mathrm{St}=$ basal area and ha $=$ hectare.

The numbers which have the same letters at the same column are not significantly differently at the top of 0,05 in the Fisher's LSD test.

Non-significant difference (ns), significant difference at: $*=0.05 ; * *=0.01 ; * * *=0.001$. 
Table 8. Dendrometric parameters persub-divisions.

\begin{tabular}{lll}
\hline Sub-divisions & $\mathbf{N}(\mathbf{s t e m s} / \mathbf{h a})$ & St. $\left(\mathbf{m}^{2} / \mathbf{h a}\right)$ \\
\hline Gobo & $31.30 \pm 5.95^{\mathrm{bc}}$ & $61.91 \pm 27.69^{\mathrm{ab}}$ \\
Guere & $24.70 \pm 8.27^{\mathrm{c}}$ & $48.05 \pm 14.84^{\mathrm{b}}$ \\
Kaikai & $36.63 \pm 3.88^{\mathrm{b}}$ & $104.41 \pm 4.95^{\mathrm{a}}$ \\
Kalfou & $44.63 \pm 7.67^{\mathrm{a}}$ & $88.24 \pm 13.71^{\mathrm{ab}}$ \\
ANOVA & $\mathrm{F}=13.55$ & $\mathrm{~F}=2.51$ \\
& $\mathrm{P}=0.0000$ & $\mathrm{P}=0.0830$ \\
& $* * *$ & $\mathrm{~ns}$ \\
\hline
\end{tabular}

$\mathrm{N}=$ density, $\mathrm{St}=$ basal area, ind. $=$ Individual and $\mathrm{ha}=$ hectare.

The numbers which have the same letters at the same column are not significantly differently at the top of 0,05 in the Fisher's LSD test.

Non-significant difference (ns), significant difference at: $*=0.05 ; * *=0.01$; $* * *=0.001$.

\subsection{Dendrometric Characteristics}

Table 7 presents the density of the populations and basal area of the individual species according to the villages. It appears from this Table that, the density varies according to the villages $(\mathrm{P}=0.0035)$ and ranges between $14.89 \pm 3.27$ ind./ha to $55.44 \pm$ 10.49 ind./ha in average significantly higher density was observed in Kalfou-center compared to the others villages The more weakly density was observed in Bangana (Table 7).
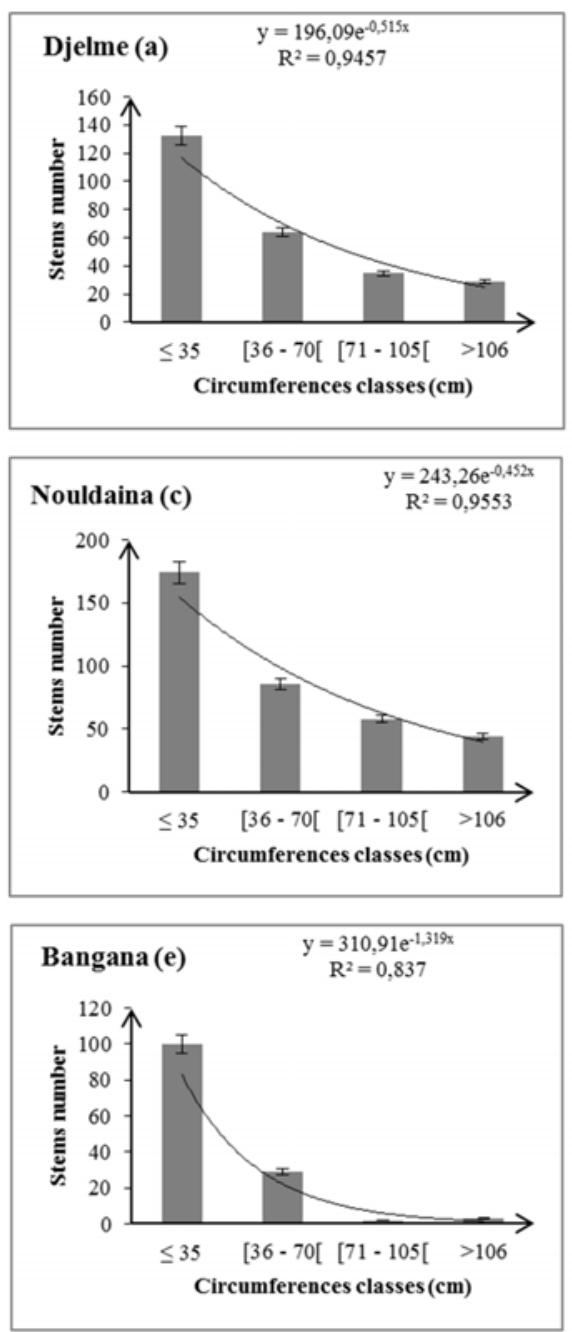

Depending on the density at the stand level, the Kalfou subdivisionis the highest, more over the Guere subdivision is the lowest (Table 8). The results of the analysis of variance carried out for the density of the populations of the different sites reveal significant differences between the villages $(\mathrm{P}=0.0035<0.05)$ (Table 7) and between the sub-divisions $(\mathrm{P}=0.0000<0.05)$ (Table 8 ) and their interaction in terms of density. As for the basal area, it varies on average between $109.64 \pm 22.93 \mathrm{~m}^{2} /$ ha and $23.01 \pm 13.17 \mathrm{~m}^{2} /$ ha and is of lower value in Bangana and Kononaye (Table 7). On the other hand, the highest values are observed in Vagandja, Madalam and Bougaye (Table 7). According to the stands, the Kaikai sub-division represents the highest value while the Guere sub-division shows the lowest value (Table 8). The analysis of variances shows a non-significant difference between the villages ( $\mathrm{P}=0.4147>0.05)$ (Table 7) and neither between the sub-divisions $(\mathrm{P}=0.0830>0.05)$ (Table 8$)$.

The diametric structure of the trees generally has an "inverted J" shape (Figure 2). The distribution of trees from different sites shows that the individuals with a diameter of less than $35 \mathrm{~cm}$ are the most numerous (Figure 2). Above 70 $\mathrm{cm}$, trees become rare (Figure 2). It is the same observation following all the sites.
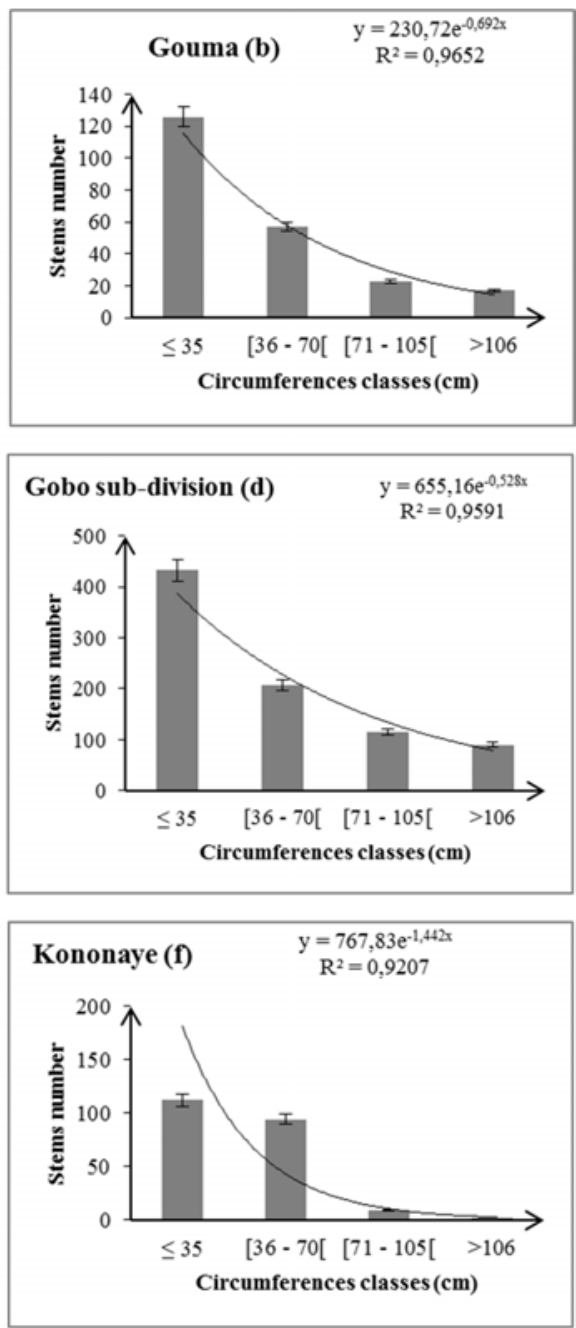

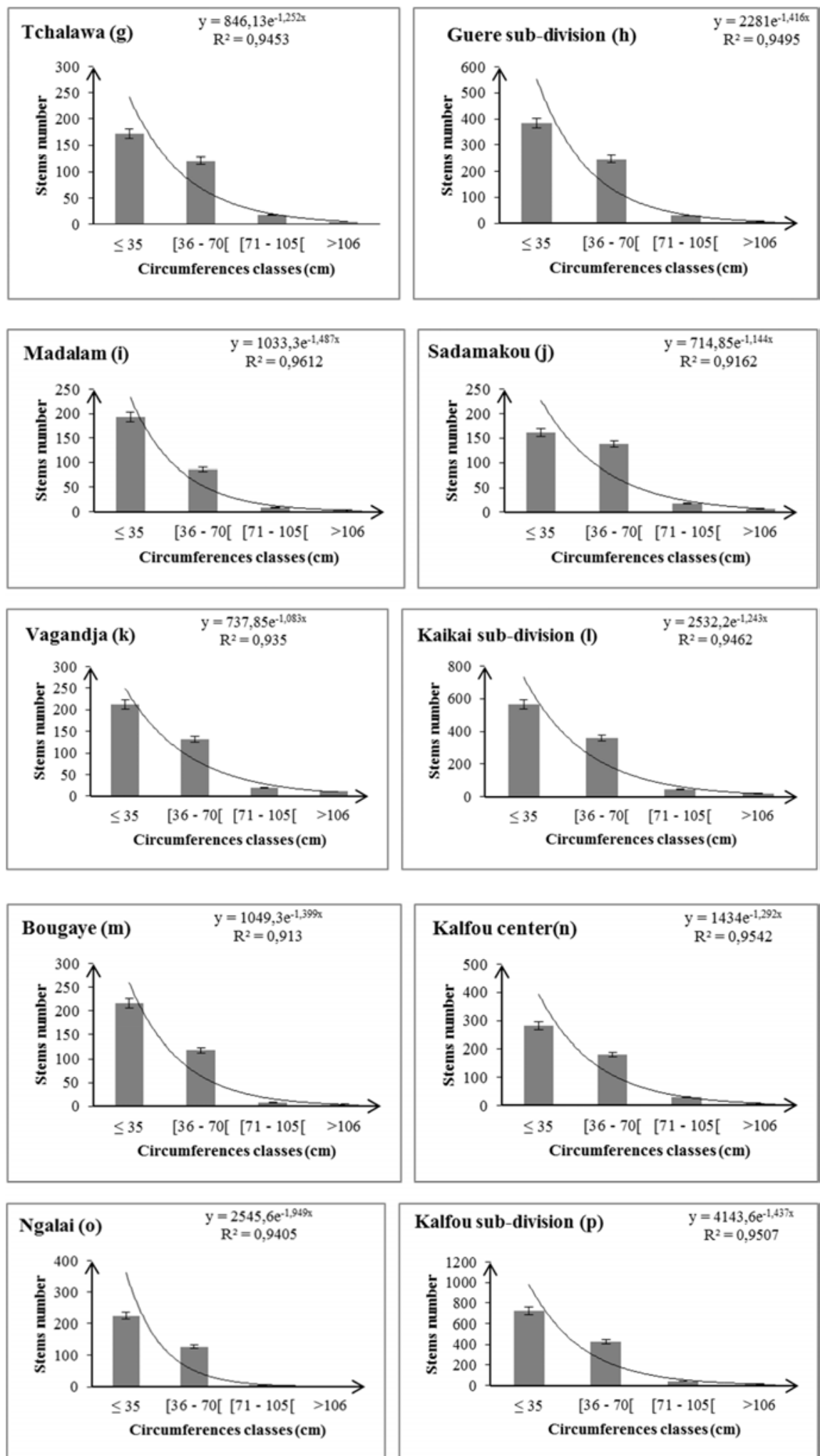

Figure 2. Distribution of individuals by circumferences classes by villages and sub-divisions.

The vertical distribution of the individuals presents a shape which is in the form of a "bell" for the majority of the sites (Figure 3) except those of Bangana, Kononaye and the Guere sub-division which present a curve in the shape of an "inverted J" (Figure 3 (e), (f) and (h)). The maximum of the trees is concentrated at the height between 10 and $20 \mathrm{~m}$ for the majority unlike those of the sites of Bangana, Kononaye and the Guere sub-division stand where the majority of the individuals have a height less than or equal to 10 (Figure 3 (e), (f) and (h)). 

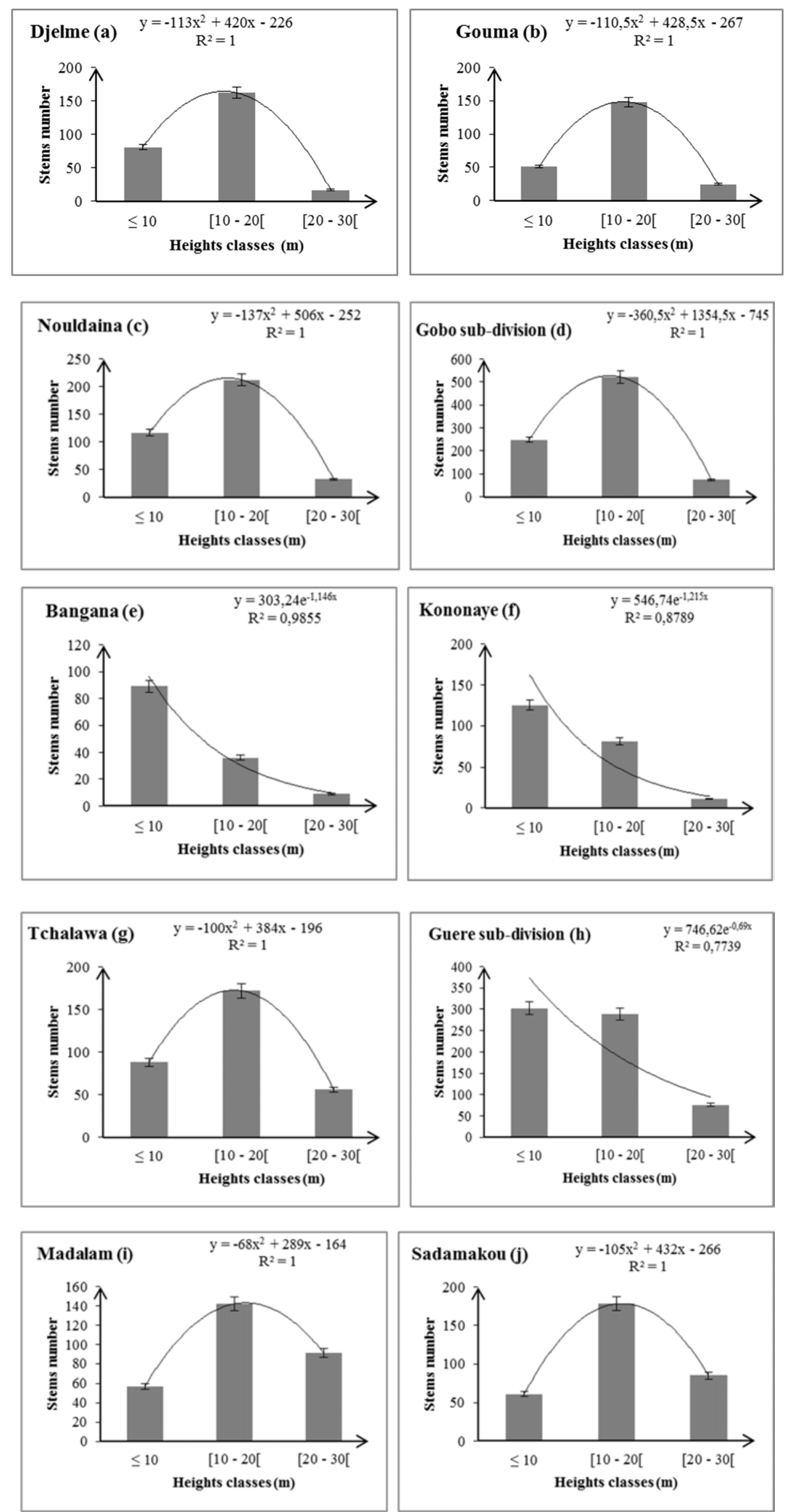

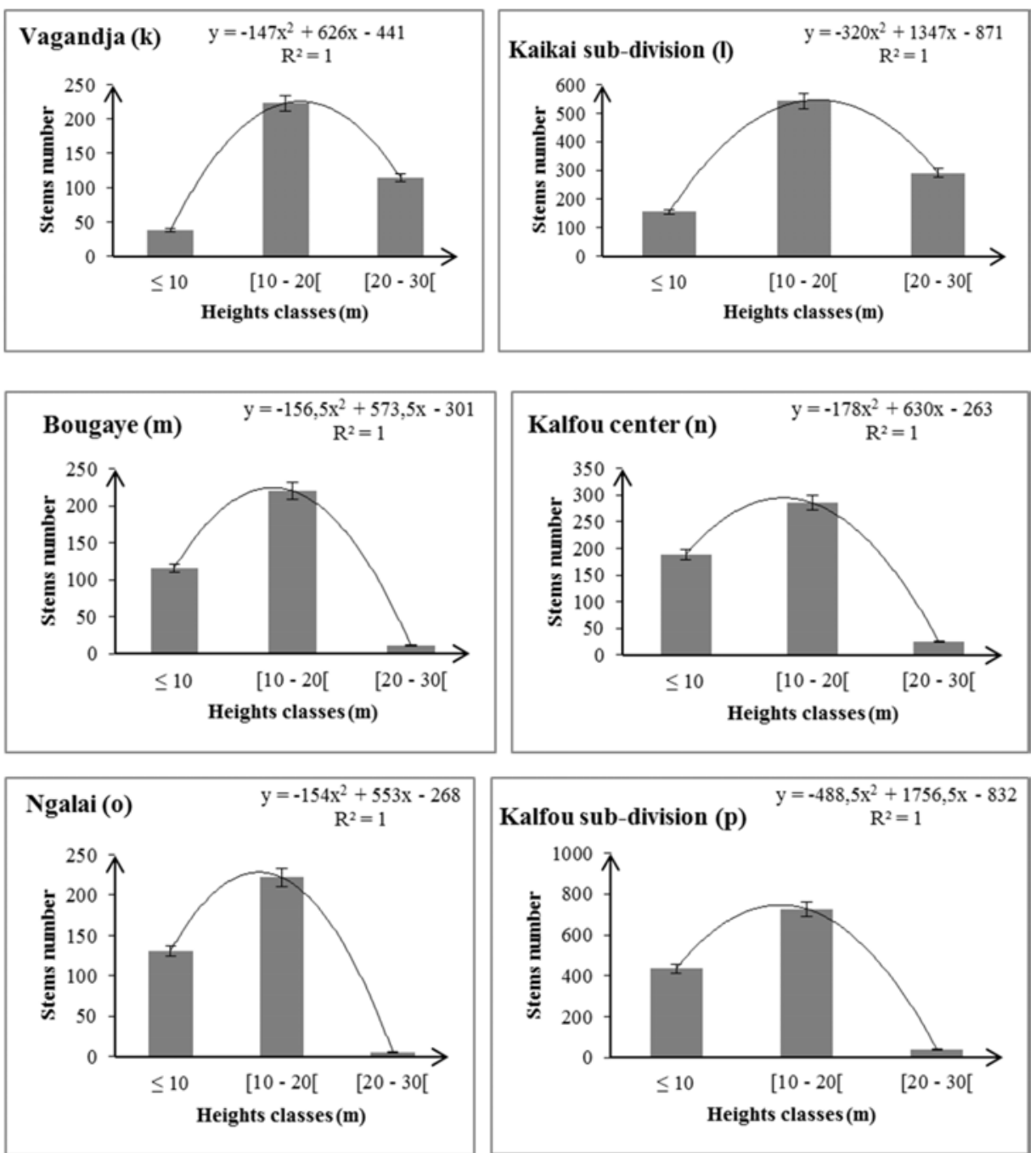

Figure 3. Distribution of individuals by height classes by villages and districts.

\section{Discussion}

\section{Floristic diversity}

The present study on the woody stands of the Mayo-Danay division reveals that out of all the surveys that have been carried out, 56 species distributed among 42 genera and 25 families. Our results are not similar to those obtained in Kalfou forest reserve which were 86 species, 58 genera and 28 families [25]. This could be explained by the strong demographic growth which leads to the enlargement of the cultural space in this study area. on the one hand, but also because of its study area which is a protected area, hence anthropogenic action is limited unlike our study area which is the natural ecosystem. Our results are similar to those obtained in a natural savannah ecosystem, subject to various anthropogenic disturbances in the Sudano-Sahelian zone North Cameroon (Laf) with 45 woody species [42]. However, our results were different from those obtained in Senegal precisely on Ferlo flora, with 20 species belonging to 18 genera and 12 families, and in Katane forest reserve in northern Ferlo with 23 species distributed between 18 genera and 13 families [33, 43]. Compared to those results, our study site wass quite rich.

The Shannon index measured was on average higher for all the stands, but varied according to the sites. It was higher in Kalfou-center, Nouldaina and weakly represented in Bangana and Kononaye. All the sites had an index greater than 03 bits except that of the Bangana site. The Shannon index values of this magnitude indicate that the diversity of vegetation on the site is important [44]. This confirms that the woody stand is more diverse in the villages of Kalfoucenter, Nouldaina and less diverse in the village of Bangana. Indeed, an author indicates that the Shannon index gradually increases until it is around 5 at the final stage of maturation [45]. Piélou's evenness index follows the same trend as that of Shannon. It is in the Bangana and Kononaye sites where the distribution of individuals across species is less equitable as stated in some studies: evenness tends to 0 when all the sampled individuals belong to the same species, it tends to 1 when individuals are fairly distributed across species [38]. This shows a particular dominance over the distribution of individuals of the different species of these sites, but also a greater stability of these same sites compared to the others. 
The ecological significance of the species differs from one site to another. The high values of important ecological value of species like Balanites aegyptiaca, Anogeissus leiocarpus and Acacia seyal could be explained on the one hand by the fact that these are more adapted to the climatic conditions of this agroecological zone, but also by their frequency due to their importance for the local population who protect these species.

The predominance of families in importance of Combretaceae, Mimosaceae and Caesalpinoideae over other families is explained by the abundance of individuals of these families in the study area. This predominance could also be explained by the fact that these families are characteristic of African savannas [46-48]. These families are common in most of the wooded savannah mosaics in Africa and more typical of the Sudano-Sahelian area [41].

\section{Dendrometric characteristics}

The density of trees fluctuates from one site to another. It is of very high value in the villages of Kalfou-center, Vagandja and Nouldaina due to the fact that anthropogenic activities which seem less accentuated in these sites. On the other hand in the villages of Bangana, Kononaye and Gouma, they have the lowest values in density respectively, because of the anthropogenic activities which are more accentuated through the production of firewood, charcoal and logging at flush with woody species during clearing for agricultural plots.

The basal area varies according to the sites. The importance of the observed values of the basal area in the village of Vagandja, and Bougaye, would be explained by the fact that the species which have very large diameters are dense in these sites while the basal area is a function of the diameter. These results are in agreement with those obtained in Ferlo [49]. Unlike the other villages, those of Kononaye and Bangana have a low value in basal area, this would be due to the activities of making charcoal and removing wood related to various other uses. These results are in agreement with those obtained the northern part of Ferlo [33, 40].

The structure of the woody stand of the Mayo-Danay division established according to the diameter classes shows a predominance of the first classes for all sites and presents the form of "inverted J", reflecting a reduction in the number of stems when passing classes from small diameters to larger diameter classes. Such diametric distribution of woody individuals indicates a disturbed environment, in full reconstruction [50, 51]. This scarcity of large-diameter species is explained by a disturbance in savannah ecosystems due to the overexploitation of woody species by humans. These results agree with those conducted in Yappo-Abbe forest classified, South Ivory Coast [52].

The structure of the stand according to the height classes shows that the individuals are more represented by the second class, whose height is between [10-20 m], on the other hand the lowest value is that of the last class [20-30 m]. Individuals whose height is less than or equal to $10 \mathrm{~m}$ is moderately represented. This confirms the high proportion of relatively more or less adult individuals, constituting a tree savannah. The stand-scale structure shows a very large distribution of individuals at the level of the second classes of height and circumference. This indicates that, the tree strata are predominant in the area. This is due to the fact that everywhere in the area, the species are highly exploited.

\section{Conclusion}

The study permitted to assess the floristic composition and structural characteristic of the woody vegetation in savannah ecosystems of Mayo-Danay Division. A total of 57 species grouped in 43 genera and 26 families was recorded. The Shannon diversity index varied from 2.93 to 4.82 bits. The analysis of variances revealed a non-significant difference between villages (ANOVA, $p=0.15 ; \alpha=0.05$ ). The most important species in terms of importance value index (IVI) and which are found in all the sites of our study area were respectively Balanites aegyptiaca (60.21), Anogeissus leiocarpus (52.15) and Acacia seyal (49.59). Structural paramaters revealed a regressive evolution of the woody stand with a very high proportion of species of small circumference and medium height. The floristic composition and the dendrometric characteristics thus observed make it possible to affirm that the woody vegetation is more and more degraded under anthropogenic action and climate change. Results of this study will allow to consider reforestation as solution to the degradation of savannah ecosystems in Mayo-Danay Division.

\section{Acknowledgements}

Our acknowledgement goes to the traditional, administrative authorities and the local populations of the 12 villages of the four sub-divisions (Gobo, Guere, Kaikai and Kalfou) of the Mayo-Dany divisionfor their contribution to the realization of these field works. We also thank all the anonymous readers of our manuscript.

\section{References}

[1] Hardoy J. E., George, Diana Mitlin and David Satterthwaite. 1992. Environmental Problems in Third World Cities. London: Earthscan Publications Ltd. 302 p.

[2] FAO, 2001. La foresterie urbaine et peri-urbaine. 95 p.

[3] Soubeiga K. J., 2004. Analyse de la demande desproduits forestiers non ligneux dans l'alimentation des ménages ruraux: cas des départements de Bondokuy (Mouhoun) et de Niandialia (Boulkiemdé). Mémoire d'Ingénieur en Sociologie et Economie Rurales. Université Polytechnique de BoboDioulasso, Burkina Faso. 57 p.

[4] FAO et WWF, 2008. Cercle de concertation des partenaires du MINFOF, thématique sur les produits forestiers non ligneux (PFNL) au Cameroun. Rapport final. 26 p.

[5] Millogo-Rasolodimby J., 2001. L'Homme, le climatet les ressources alimentaires végétales en périodes de crises de subsistance au Burkina Faso au cours du $20^{\text {ème }}$ siècle. Thèse d'Etat en Biologie et Ecologie Végétales. Université de Ouagadougou, Burkina Faso. 249 p. 
[6] Popoola L., 2001. The role of women in sustainable management of Non timber forest product. In role of women in forestry and environnemental development. Proceeding of annual Workshop of foresty vocational training center. Drayi, Kano. pp. 14-19.

[7] Fontès J, Guinko S., 1995. Carte de la végétation et de l'occupation des sols du Burkina-Faso. Notice explicative, Ministère de la coopération française, projet Campus, Toulouse. 68. p.

[8] RGPH, 2011. Troisième Recensement Général de la Population et de l'Habitat. Rapport technique de l'analyse des données, 1 (8): 118.

[9] Degrande A., Essomba, H., Bikoue Mekongo, C. et Kamga, A., 2007. Domestication, genre et vulnérabilité. Participation des femmes, des jeunes et des catégories les plus pauvres à la domestication des arbres agroforestiers au Cameroun. ICRAF Working Paper No. 48. Yaounde, ICRAFWCA/HT. 73 p.

[10] Mapongmetsem P. M. et Laissou M., 2011. Contribution à la domestication des fruitiers locaux; influence des substrats et des substances de croissance sur l'enracinement des marcottes de huit espèces présentes au Cameroun. Annales de la Faculté des Arts, Lettres et Sciences Humaines de l'Université de Ngaoundéré. 12: 117-133.

[11] Betti JL., 2001. Vulnérabilité des plantes utilisées comme antipaludiques dans l'arrondissement de Mintom au sud de la réserve de biosphère du Dja (Cameroun) publié par National Botanic Garden of Belguim. Systematic and geography of plants, 71 (2): $661-678$.

[12] Ouédraogo I., 2008. Diversité des espèces ligneuses utiles de la région du Nord du Burkina Faso; état des peuplements de cinq espèces d'importance socio-économique. Mémoire d'Ingénieur en Eaux et Forêts. Université de Bobo-D, Burkina Faso. 68 p.

[13] Traoré L., 2008. Inventaire des espèces ligneuses utilitaires de la région Sud-Ouest du Burkina Faso et état des populations de trois espèces à haute valeur économique. Mémoire de DEA en Sciences Biologiques Appliquées. Université de Ouagadougou, Burkina Faso. 46 p.

[14] Agali AB., 2009. Diversité, structure et perceptions locales des espèces ligneuses fourragères dans le terroir de Torodi, Ouest Niger. Mémoire de DEA en Biologie et Ecologie végétales. Université de Ouagadougou, Burkina Faso. 48 p.

[15] Belem B, Olsen CS, Theilade RB, Guinko S, Lykke AM, Diallo A. et Boussim IJ., 2008. Identification des arbres hors forêt préférés des populations du Sanmatenga (Burkina Faso). Revue Bois et Forêts des tropiques 298 (4): 53-64.

[16] Fay, P. A., Kaufman, D. M., Nippert, J. B., Carlisle, J. D., and Harper, C. W., 2008. Changes in grassland ecosystem function dueto extreme rainfall events: implications for responses to climate change, Glob. Change Biol. 14: 1600-1608.

[17] Fokunang CN, Ndikum V, Tabi OY, Jiofack R. B, Ngameni B., Guedje N. M., Tembe-Fokunang, E. A., Tomkins P., Barkwan S., Kechia F., Asongalem E., Ngoupayou J., Torimiro N. J., Gonsu K. H., Sielinou V., Ngadjui B. T., Angwafor III F., Nkongmeneck A., Abena OM., Ngogang J2, Asonganyi T.,, Colizzi V., Lohoue J. et Kamsu-Kom, 2011. Afr J Tradit Complement Altern Med. 8 (3): 284-295.

[18] Jiofack T, Fokunang C, Guedje N, KemeuzeV, Fongnzossie E, Nkongmeneck BA, Mapongmetsem PM, Tsabang N. 2010.
Ethnobotanical uses of medicinal plants of two ethnoecological regions Cameroon. International Journal ofMedicine and Medical Sciences, 2 (3): 60-79.

[19] Dogmo, 2002. «Etudes floristiques et ethnobotaniques dans un village de la zone forestière du Cameroun: Cas de Nkolbibanda ». $72 \mathrm{p}$.

[20] Fotsing E. et Madi A., 1997. Evaluation et suivi de la Dynamique de la Biomasse Ligneuse par Images Satellites: Rapport de Recherche $\mathrm{n}^{\circ} 13$, Yaoundé University and United Nations University. 38 p.

[21] Fotius G., 1974. Rapport préliminaire sur la végétation du Nord-Cameroun. Office de la recherche scientifique et technique OUTRE-MER. $20 \mathrm{p}$.

[22] Letouzey R., 1968. Etude phytogéographique du Cameroun. Lechevalier, Paris. $511 \mathrm{p}$.

[23] GIZ, 2013. Schéma Directeur d'Approvisionnement Urbain en Bois-Energie Ville de Maroua. Le Programme d'appui au Programme Sectoriel Forêts et Environnement (ProPSFE). 88 p.

[24] Wafo T. G. et Huynh F., 2009. Caractérisation et suivi de recul des ligneux dans les aires protégées du nord Cameroun analyse par télédétection spatiale dans la réserve de Kalfou. Journée d'animation scientifique (JAS09) de l'AUF Alger, Novembre 2009. 7 p.

[25] Froumsia M., Zapfack L., Mapongmetsem P. M. and Nkongmeneck B.-A., 2012. Woody species composition, structure and diversity of vegetation of Kalfou Forest Reserve, Cameroon. Journal of Ecology and the Natural Environment, 4 (13): 333-343.

[26] Haiwa Gilbert, Tchobsala and Ngakou Albert., 2016. Structure, Dynamic of Regeneration and Ecological Characterization of Vegetation of the Sudano-Sahelian Zone of Cameroon. Int. J. Curr. Res. Aca. Rev. 4 (9): 21-52.

[27] Tchobsala, Vroumsia T. and Lirawa P., 2016. Exploitation of ligneous species in the forestry massif of dana (mayo-danay, cameroon). Asian ResearchJournal of Multidisciplinary (AARJMD), 3 (8): 2319-2801.

[28] Baïyabe Il-Mataï, Tchobsala, Dongock Nguemo Delphine., Mapongmetsem Pierre Marie., 2018. Dynamic and ecological characteristics of rewooded sites of the Sudano -Sahelian zone (Far North, Cameroun). Int. J. Adv. Res. Biol. Sci. 5 (3): 88-102.

[29] Sieffermann G. et Vallerie M., 1963. Le quaternaire sol du Mayo-Dany. ORSTOM-Cameroun. 30 p.

[30] PNDP(Programme National de Développement Participatif), 2013. Plan Communal de Developpement (PCD) de Yagoua. $307 \mathrm{p}$.

[31] Sonke B., 1998. Étude floristique et structurale des forêts de la Réserve de faune du Dja (Cameroun). Thèse de Doctorat, Université Libre de Bruxelles. 267 p.

[32] Diallo A, Agbangba EC, Thiaw A, Guissé A., 2012. Structure des populations de Acaciasenegal (L.) Will dans la zone de Téssékéré (Ferlo nord), Sénégal. Journalof Applied Biosciences, 59: 4297-4306

[33] Niang K, Ndiaye O, Diallo A, Guissé A., 2014. Flore et structure de la végétation ligneuse le long de la Grande Muraille Verte au Ferlo, nord Sénégal. Journal of AppliedBiosciences, 79: 6938-6946. 
[34] Arbonnier M. 2004. Arbres, Arbustes etLianes des Zones Sèches d'Afrique del'Ouest (4ème édn). CIRADMARGRAFMNHN: Montpellier France. 573 p.

[35] Shannon, C. E. \& Weaver, W. (1949). The Mathematical Theory of Communication. Urbana, IL: University of Illinois Press. 3 p.

[36] Legendre L. et Legendre P., 1984. Ecologie numérique 2- La structure des données écologiques. Masson collection d'écologie. 335 p.

[37] Devineau JL, Lecordier C. et Vuattoux R: 1984. Évolution de la diversité spécifique du peuplement ligneux dans une succession préforestière de colonisation d'une savane protégée des feux (Lamto, Côte-d'Ivoire). Candollea, 39 (1): 103-134.

[38] Ramade F, 1990. Éléments d'écologie. Écologiefondamentale. Mc GRAW-HILL., Paris. 403 p.

[39] Curtis J. T., McIntosh R. P., 1951. An upland forest continuum in the prairie forest border region of Wisconsin. Ecology, 32 (3): 476-496.

[40] Ndiaye O, Diallo A, Stephen AW, Guissé A., 2014. Structural Diversity of Woody Species in the Senegalese Semi-Arid Zone-Ferlo. American Journal of Plant Sciences, 5: 416-426.

[41] Letouzey R., 1985. Carte phytogéographique du Cameroun au 1/500.000. 1) [Sahelian and Sudanese domain] Domaine sahélien et soudanien. IRA (Herbier National), [Institute of the International map of vegetation. Toulouse, 1-26] Institut de la Carte Internationale de la Végétation. Toulouse. pp. 1-26.

[42] Ntoupka M. 1999. Impact des perturbations anthropiques (pâturage, feu, et coupe debois) sur la dynamique de la savane arborée en zone soudano-sahélienne du Nord du Cameroun, thèse de Doctorat de l'université, Paul Valery-Montpellier III. $260 \mathrm{p}$.

[43] Ndiaye I, 2008. Flore et végétation ligneuses du terroir de Katané dans la réserve de faune du Ferlo-nord. Mémoire de DEA, FST. 25 p.
[44] Dona A., Mapongmetsem P. M., Dongock N. D., Pamboudem N. A., Fawa G. \& Aoudou D. S., 2016. Phytodiversity and carbon stock in Sudanian savannahs zone of Tandjile-East of Chad. International Journal of Applied Research, 2 (9): 455460.

[45] Frontier, S., 1999. Les Écosystèmes. Presse Universitaires de France, Coll. Que sais-je ?, Paris. 128 p.

[46] Nacoulma B., 2012. Dynamique et stratégie de conservation de la végétation et de la phytodiversté du complexe écologique du Parc National du W du Burkina-Faso. Thèse Unique, Univ. Ouagadougou. $153 \mathrm{p}+$ Annexes.

[47] Gnoumou A., 2013 Diversité et dynamique spatiotemporellede la végétation de la forêt classée de la réserve partielle de faune de la Comeo-Léraba (Sud-ouest du Burkina-Faso). Thèse Unique, Univ. Ouagadougou. 183 p.

[48] Melom S., Mbayngone E., Bechir A. B., RatnanN. et Mapongmetsem P. M.: 2015. Caractéristiques floristique et écologique des formations végétales de Massenya au Tchad (Afrique centrale), Journal of Animal \& Plant Sciences, 25 (1): 3799-3813.

[49] Ndiaye O., 2013. Caractéristiques des sols, dela flore et de la végétation du Ferlo, Sénégal. Thèse de doctorat unique en biologie végétale, option écologie, FSTUCAD. 114 p.

[50] Nusbaumer L., Gautier L., Chatelain C. et Spichiger R., 2005. Structure et composition floristique de la forêt classée de Scio. Candollea, 60 (2) 393-443.

[51] Bouko S. B., Sinsin B., Soulé, G. B., 2007. Effets dela dynamique d'occupation du sol sur la structure et la diversité des forêts claires et savanes du Bénin. Tropicultura, 25 (4): 221-227.

[52] Konan D., Bakayoko A., Tra Bi F. H., Bitignon B. G. A. et Piba S. C., 2015. Dynamique de la structure diamétrique du peuplement ligneux des different biotopes de la forêt classée deYapo-Abbé, Sud de la Côte d'Ivoire. Journal Applied Biosciences, 94: 8869-8879. 